\title{
Effects of soil surface disturbances after logging on plant functional types
}

\author{
Hélène GONDARD ${ }^{\mathrm{a} *}$, Marc DECONCHAT ${ }^{\mathrm{b}}$ \\ ${ }^{a}$ Centre National de la Recherche Scientifique, Centre d'Écologie Fonctionnelle et Évolutive, UMR 5175, 1919 route de Mende, \\ 34293 Montpellier Cedex 5, France \\ ${ }^{\mathrm{b}}$ Institut National de la Recherche Agronomique, BP 27, 31326 Castanet-Tolosan, France
}

(Received 10 July 2002; accepted 2 June 2003)

\begin{abstract}
Soil surface disturbances after logging influence plant species diversity. To estimate these effects, the objective of the present study was to test three hypotheses: (1) each soil surface disturbance type is characterized by a group of plant species that emerges following the disturbance, (2) each emergent group of plant species has distinct, recognizable biological traits, (3) in two different bio-geographic plant communities, each soil surface disturbance type is characterized by the same set of biological traits. We present results from Atlantic oak (Quercus pubescens Willd., Q. robur L. and Q. petraea (Mattuschka) Liebl.) coppices and natural Mediterranean Aleppo pine (Pinus halepensis Miller) forests of southern France. Both studies use the same methodology based on a typology of soil surface perturbation 1-3 years after logging combined with a vegetation inventory. Plant functional traits (morphological, life history and regeneration), not necessarily linked with taxonomic attribution, were used to constitute putative functional groups to allow comparison between the two studies. Results were similar in the two studies and confirmed the working hypotheses.
\end{abstract}

plant species / logging / soil surface disturbance / life traits

Résumé - Effets des perturbations de la surface du sol dues à l'exploitation forestière sur la diversité végétale. Les perturbations de la surface du sol dues à l'exploitation forestière sont susceptibles d'agir sur la diversité végétale. Pour estimer ses effets, l'objectif était de tester trois hypothèses: (1) chaque type de perturbation de la surface du sol est caractérisé par un groupe d'espèces qui se présente après la perturbation, (2) ces groupes d'espèces ont des traits biologiques distincts, (3) dans deux communautés bio-géographiques différentes, chaque type de perturbation de la surface du sol est caractérisé par les mêmes traits biologiques. Nous présentons les résultats obtenus dans le cas de taillis de chênes (Quercus pubescens Willd., Q. robur L. and Q. petraea (Mattuschka) Liebl.) de la région atlantique et des forêts de pin d'Alep (Pinus halepensis Miller) de la région méditerranéenne du sud de la France. La méthodologie, utilisée dans les deux études, est basée sur une typologie des perturbations de la surface du sol dans les trois premières années qui suivent l'exploitation forestière combinée avec des relevés de végétation. Des traits fonctionnels (traits morphologiques, d'histoire de vie et de régénération), sans attribution taxonomique particulière, ont été utilisés pour permettre une comparaison entre les deux études. Les résultats étaient similaires dans les deux études et confirment les hypothèses.

diversité végétale / exploitation forestière / perturbation de la surface du sol / traits de vie

\section{INTRODUCTION}

In recent years, there has been much concern about the impact of forest management practices on biodiversity $[8,19$, 52]. Society increasingly demands that forest managers reduce the negative influences of their exploitation practices on biodiversity, especially during logging operations that are the most obvious human perturbations on forests. Consequently, considerable research has been carried out on this topic, especially concerning plant species diversity which is a component of prime importance in terrestrial ecosystem functioning [2, 7 , 34].

Plant species diversity in managed temperate forests is generally strongly modified just after logging perturbations, with an increase of species richness [26, 31]. When the canopy closes, species richness decreases and can return to its former level [32]. However, even if species richness decreases, rare species can develop in old forests and thus yield enhanced conservation value $[11,61]$. Logging changes canopy structure and induces large understorey modifications with regards to light $[21,67]$, rainfall distribution on soil $[1,10]$, temperature and humidity [9], as well as chemical and microbiological soil properties [18, 37, 44, 51]. All these factors have effects on species diversity and thus on resistance [43], resilience [58] and overall functioning of ecosystems. The modifications of the ground surface, such as slash deposition and litter removal, created by logging operations, are suspected to be possible driving factors of plant species diversity. These perturbations

\footnotetext{
* Corresponding author: gondard@ cefe.cnrs-mop.fr
} 
of the ground surface create a heterogeneity that could have consequences on plant species diversity $[15,27,56]$.

To analyze ecosystem responses to disturbances, life traits appear to be an excellent tool [31, 42]. Indeed, plant functional types can be defined as comprising species that respond in a similar fashion to specific environmental factors, as a result of their shared biological traits [40]. Functional classifications, based on life traits, give biological robustness and cross-regional comparability to models and field studies [38]. Life traits are morphological, physiological or ecological traits, not necessarily linked with taxonomic attribution [50]. Thus, plant functional classification has recently received much attention from ecologists even though functional classifications of species are known and used since quite some time [66]. The use of life traits for the comprehension and analysis of plant species dynamics in relation with perturbation is clearly demonstrated by many authors [16, 17, 41, 45, 47]. These authors generally concur with a general hypothesis that there exists a pattern of response to perturbation, linked to species biology, which is more or less identical for plant communities belonging to vastly different milieux and contexts [46].

The objective of the present paper is to use functional groups based on plant life traits in order to analyze effects of soil surface disturbances after commercial logging on plant species diversity. For that purpose, we test three hypotheses: (1) each soil surface disturbance type is characterized by a group of plant species, (2) each emergent group of plant species has distinct, recognizable biological traits, (3) in two different bio-geographic plant communities, each soil surface disturbance type is characterized by the same set of biological traits. These hypotheses have been tested by combining two separate studies employing similar methodologies in two types of forests.

\section{MATERIALS AND METHODS}

The two types of forests studied are located in southern France. The first one, hereafter called Atlantic (ATL), is near Toulouse in a region with Atlantic climatic influence ( $800 \mathrm{~mm}$ mean annual precipitation; $11{ }^{\circ} \mathrm{C}$ mean annual temperature; $200-400$ meters above sea level; molasses substratum). Broad-leaved trees including oaks (Quercus pubescens Willd., Q. robur L. and Q. petraea (Mattuschka) Liebl.), chestnut (Castanea sativa Miller) and cherry (Prunus avium L.) are the main canopy species of the highly fragmented forests which are generally managed in coppice, and coppice with standards, since several centuries. There are few recent afforestations in the area and most of the woodlots were already present before the beginning of the twentieth century judging by old maps. This area has been studied in 1998 [13].

The second area studied in 1999 [25], hereafter called Mediterranean (MED), is near Draguignan, in southeastern France, in a region with Mediterranean climatic conditions $(800 \mathrm{~mm}$ mean annual precipitation; $14{ }^{\circ} \mathrm{C}$ mean annual temperature; $200-300 \mathrm{~m}$ a.s.l; limestone substrate) [39]. The studied forests are composed of Aleppo pine (Pinus halpensis Miller) stands, with evergreen holm oak (Quercus ilex L.) and downy oak (Quercus pubescens Willd.) in the under canopy. Since the nineteenth century, abandonment of olive trees and vineyards culture, the decline of grazing, and the spread of plant diseases have favoured the expansion of Aleppo pine to the detriment of holm oak $[3,60]$. This pine is a transient species which, being unable to reproduce in its own understorey, is replaced by holm oak or downy oak in the absence of fire. Logs of these Aleppo pine-dominated forests are mainly harvested for transformation in regional paper pulp factories.

In these forests, the description of the ground surface, in stands logged since less than three years, was inspired from the method developed by McMahon [48]. This method is based on visual recognition of the ground surface at selected points or spots $(30 \mathrm{~cm}$ radius circle) with regard to a reference list of 23 possibilities. As many ground surface classes had low frequencies in our studies, we simplified the classes of the original reference list into three broad groups: $\mathrm{N}=$ not perturbed, $\mathrm{P}=$ perturbed (litter removed but topsoil intact, litter and topsoil mixed, rut etc.), $\mathrm{R}=$ remnant depot (slash cover deep) [14]. Data collection on plant species composition was carried out on the same spots as the ground surface description in the MED area and on a 1 square meter in ATL.

In ATL, the sample was based on two sites with 3 and 4 plots, respectively, and for each one a transect of 20 spots $(n=140)$ was set up. The transects were perpendicular to the main axis of wood transportation on the stand. In MED, the sample was based on 3 sites with five $400 \mathrm{~m}^{2}$ circular plots in each, made up by 100 spots along 3 regularly spaced diameters $(n=1500)$. These data were synthesized in order to obtain a measure of the affinity of the observed plant species for each type of ground surface. Assuming Ni, Ri, Pi were the number of presence of the species $i$ in each respective ground surface type and $\mathrm{N}, \mathrm{R}, \mathrm{P}$ the total number of samples of each type, the affinity for type $\mathrm{N}$ was calculated as: $\mathrm{FNi}=(\mathrm{Ni} / \mathrm{N}) /(\mathrm{Ni} / \mathrm{N}+\mathrm{Ri} / \mathrm{R}+\mathrm{Pi} / \mathrm{P})$, and similarly for $\mathrm{R}$ and $\mathrm{P}$. When a species was observed only in the $\mathrm{N}$ type, $\mathrm{FNi}=1$. When it was never observed, FNi $=0$. For a given species $i, F N i, F R i$ and FPi defined coordinates in a triangular system where each species was plotted for each studied area. We defined 7 groups of species called N, R, P, NP, NR, PR, NRP. The species of the group N had a specificity $\mathrm{FNi} \geq 0.75$, idem for $\mathrm{R}$ and $\mathrm{P}$, a species of the group NP had a specificity $\mathrm{FRi} \leq 0.25$ and $\mathrm{FPi} \geq 0.25$ and $\mathrm{FNi} \geq 0.25$, idem for $\mathrm{NR}$ and PR, the remaining species are in the group NRP.

To analyze the influence of ground surface modification on plant species diversity after logging, species were characterized by life traits that refer to structure and functioning [40]. We selected here the life forms, defined by Raunkiær [63], which are based on the position on the plant of renewal buds from which new organs and foliage develop after an unfavorable season, such as a cold winter. Life forms (or growth forms) give relevant and revealing information of functional ecological shifts taking place at the community or ecosystem levels $[35,55]$. Moreover, life forms effectively synthesize various life history traits, as they integrate both morphological and physiological attributes [22, 23]. The life forms selected in our study are: therophytes (annual plants), geophytes (bulbous plants), hemicryptophytes (herbaceous perennials), chamaephytes (shrubs) and phanerophytes (trees).

Dynamic ecosystem patterns and processes can also be studied by dispersal modes that are important for plant species survey and community structure [5]. Among the different classifications of species based on seed dispersal vectors [65], we selected, after examining the available data, four main dispersal modes: anemochory (seeds dispersed by wind), endozoochory (dispersal associated with ingestion of seeds by animals), epizoochory (seeds dispersed by animals without being ingested) and other dispersal vectors (seeds dispersed by water, gravity and unknown dispersal modes). We also analyzed plant species distribution as a function of their capacity to grow in a restricted area, like a logging area, by using Grime's classification system [29] which allows classifying plant species in relation to their sensitivity to stress tolerance $(\boldsymbol{S})$, competitiveness $(\boldsymbol{C})$ and ruderality $(\boldsymbol{R})$. Competitive strategy "involves selection for highly competitive ability, which depends upon plant characteristics that maximize vegetative growth in productive, relatively undisturbed conditions" [29]. By contrast, stress tolerant strategy is associated with "reductions in both vegetative and reproductive vigor, adaptations which allow 
endurance of continuously unproductive conditions arising from environmental stress, severe resource depletion by the vegetation, or the combined effect of the two" [29]. Ruderal strategy "is associated with a short life span and with high seed production and has evolved in severely disturbed but potentially productive environments" [29]. The mean positions of the species groups in the triangle defined by Grime between $\boldsymbol{R}, \boldsymbol{S}$ and $\boldsymbol{C}$ components defined the overall strategies of the groups.

Information about these various traits was obtained for the ATL site from Rameau et al. [62] for life forms and dispersal modes, and from Grime et al. [30] for Grime strategies. In the MED site, we used the data base BASECO (IMEP, Marseille, France) for all life traits [24]. This data base gives information about life traits of Mediterranean plant species from literature $[6,12,36,49,57,62,65]$.

For each group of species defined by affinity for ground surface types, we computed the proportion of species belonging to the classes defined by a given life trait. These proportions were tested against a random distribution of the species by the Pearson $\mathrm{Chi}^{2}$ test with Systat 9 when the number of species was higher than the required number of five; otherwise groups were merged [64].

\section{RESULTS}

In both study areas; plant species composition differed according to ground surface condition (Fig. 1). In both areas, of the 79 species observed in ALT and the 71 species observed in MED, only 3 species and 5 species, respectively, were exclusively associated with intact spots (i.e., not logged). Conversely, most of the species were observed in intact spots; 43 (9 NP and 34 NRP) in ATL, and 42 (7 NR, 3 NP and 32 NRP) in MED. Perturbation of the ground surface seems necessary for many species that were observed only in such situations -29 (37\% of total species richness) in ATL, and 13 (18\% of total species richness) in MED. The species associated with slash decomposition were less numerous; 0 in ATL and 4 in MED. It seems that more species have a high frequency in slash depots in MED than in ATL. Only 14 species are common between both samples (Fig. 1), but they did not have similar trends with ground surface types, except for Cytisus scoparius, Hedera helix, Ligustrum vulgare and Rubia peregrina associated with NRP, while Lolium perenne and Teucrium chamaedrys associated with $\mathrm{P}$ in the both areas.

\subsection{Raunkiær's life forms}

Geophytes, therophytes and chamaephytes were the life forms least often observed in the two areas (Fig. 2). Only one geophyte, Tamus communis, was observed in ATL - NR, and no geophyte at all was recorded in MED. We found only 8 therophytes in ATL of which 1 in N, 5 in P and 2 in NP, and only 4 therophytes in MED of which 1 in R, 2 in P, 1 in NP; most of the therophytes appeared in perturbed places. Chamaephytes represented only $7.1 \%$ of the total species richness in ATL and $11.3 \%$ in MED; they were observed in several ground surface types but with few species. Hemicryptophytes and phanerophytes were the most observed life forms in the two regions. Hemicryptophytes represented $52.5 \%$ of total species richness in ATL and 31.3\% in MED, while phanerophytes represented $31.3 \%$ of total species richness in ATL and $52.1 \%$ in MED. Thus, the statistical analyses were carried out only with these life forms. In ATL, we recorded signifi- cantly more hemicryptophytes than phanerophytes in perturbed places (P, PR, NP, NPR; $\left.\chi^{2}(2)=22.87 ; p<0.001\right)$, whereas no significant difference were found in MED $\left(\chi^{2}{ }_{(2)}=1.35 ; p>0.05\right)$. Conversely, in MED, there were more phanerophytes than hemicryptophytes in unperturbed places $\left(\mathrm{N}, \mathrm{NR}, \mathrm{R} ; \chi^{2}{ }_{(2)}=8.32 ; p<0.01\right)$, whereas no significant difference was found in $\operatorname{ATL}\left(\chi^{2}(2)=1.23 ; p>0.05\right)$.

\subsection{Dispersal mode}

Epizoochory, was the least observed mode of dispersal in all ground surface types (Fig. 3), with only 6 species in ATL (Brachypodium sylvaticum, Holcus mollis, Juncus conglomerates, Phleum pratense, Ranunculus nemorosus and Vulpia myuros), and 2 species in MED (Digitalis lutea and Galium timeroyi). The category "other dispersal modes" (seeds dispersed by water, gravity and unknown dispersal modes) represented $21.1 \%$ of total species richness in ATL and $16.9 \%$ in MED. It appeared with more than 2 species in P, NP and RP in ATL, and in P and NP in MED; it was associated with perturbed places. Anemochory and endozoochory were the most observed dispersal modes in both studied areas; anemochory represented $49.5 \%$ of the total species richness in ATL and $38.0 \%$ in MED, while endozoochory represented $23.1 \%$ of the total species richness in ATL and 42.3\% in MED. There were significantly more species characterized by anemochory in ATL than in MED $\left(\chi^{2}(2)=4.05 ; p<0.05\right)$, and significantly more with endozoochory in MED than in $\operatorname{ATL}\left(\chi_{(2)}^{2}=5.70\right.$; $p<0.05)$. In ATL, anemochory was observed in N, P, NR, NP, and only one species in NRP, thus essentially in unperturbed and perturbed places. In MED, anemochory was observed in all ground surface types but it was more present in NP and RP. In ATL, endozoochory was higher in NP and P than in the other ground surface types. In MED, endozoochory was higher in P, NP and NRP.

\subsection{Grime's strategies $S, C$ and $R$}

All the groups of species were characterized by competitive and stress tolerant $(\boldsymbol{C S})$ strategies than ruderal $(\boldsymbol{R} \leq 0.3)$ (Fig. 4). In ATL, group species related to P (P, PR, NP) have high values for the sensibility to perturbation $(\boldsymbol{R})$, group species related to $\mathrm{R}(\mathrm{R}, \mathrm{NR}, \mathrm{PR})$ have high values for the sensibility to competition $(\boldsymbol{C})$ and group species related to N (N, NP, NR) had high values for sensibility to stress $(S)$. In MED, group species related to $\mathrm{P}, \mathrm{PR}$ and NR showed high value for perturbation $(\boldsymbol{R})$, groups species related to PR, NR and NP showed high value for competition $(\boldsymbol{C})$, and groups species related to N, R and NP showed high value for stress $(\boldsymbol{S})$. Thus, in MED there was not one strategy $(\boldsymbol{S}, \boldsymbol{C}$ or $\boldsymbol{R})$ more associated with one ground surface type $(\mathrm{P}, \mathrm{R}, \mathrm{N})$ than the others.

\section{DISCUSSION}

Analyzes carried out concerning effects of soil surface disturbances after logging on plant species diversity allowed us to confirm or partially confirm our three hypotheses. Hypothesis (1), that each soil surface disturbance type is characterized by a group of plant species, was verified. In the two areas, Atlantic 


\section{ATLANTIC AREA}

Crepis setosa

Hypericum perforatum

llex aquifolium

Hypericum hirsutum

Inula conyza

Betula pendula

Coryius avellana.

Castanea sativa

Viola riviniana.

Luzula sp.

Cornus sanguinea

Quecus robur

Hypericum androsaemum

Danthonia decumbens

Rubia peregrina

Hedera helix.

Carexsp.

Lonicera periclymenum

Teucrium scorodonia

Quercus pubescens

Rubus fruticosus

Lonicra xylos teum

Agrostis capillaris

Cirsium sp.

Epilobium tetragonum

Junciperus oxucedrus

Hypericum pulchrum

Ros a arvens is

Tamus communis

Crataegus monogyna

Prunus avium

Sorbus tominalis

Polypodium vulgare

Ranunculus nemorosus

Ajuga reptans

Ligustrum vulgare

Prunus spinosa

Cyt isus scoparius

Centaurium erythraea

Veronica officinalis

Salix cinerea

Ruscus aculeatus

Carex flacca

Leucanthemum vulgare

Solidago canadens is

Fraxinus excelsior

Holcus mollis

Vicia tenuifolia

Solanum dulcamara

Agrostis stolonifera

Anagallis arvens is

Brachypodium pinnatum

Calluna vulgaris

Carpinus betulus

Clematis vitalba

Crepis capillaris

Deschampsia sp.

Epilobium hirsutum

Hieracium picroïdes

Hypochoeris maculata

Juniperus communis

Lolium perenne

Lotus uliginos us

Melampyrum pratense

Molinia caenulea

Picris echioìdes

Poa nemoralis

Poa trivialis

Populus tremula

Salix aurita

Sonchus asper

Sorichus oleraœus

Stachys officinalis

Taraxacum officinale

Teucrium chamaedrys

Veronia chamaedrys

Vulpia myuros

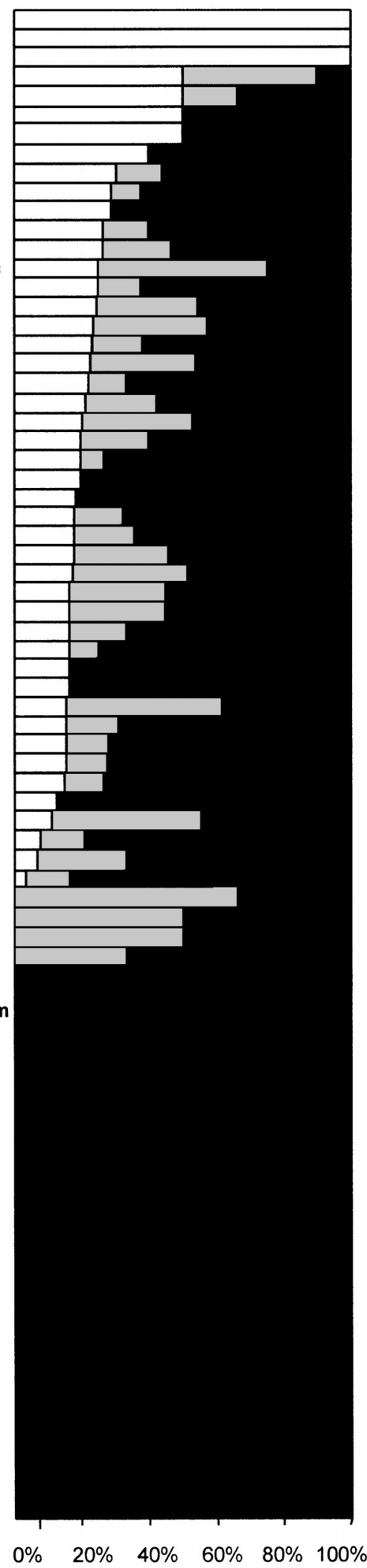

\section{MEDITERRANEAN AREA}

Catananche caerulea

Helianthemum oelandicum

Juniperus communis

Osyris alba

Spartium junceum

Juniperus oxycedrus

Calicotome spinosa

Lathyrus setifolius

Asparagus acutifolius

Clematis vitalba

Pistacia terebinthus

Hieracium pilosella

Staehelina dubia

Lonicera implexa

Quercus ilex

Carex halleriana

Vibumum tinus

Hedera helix

Brachypodium pinnatum

Poa nemoralis

Ligustrum vulgare

Acer campestre

Pistacia lentiscus

Sorbus aucuparia

Brachypodium sylvaticum

Aphyllanthes monspeliensis

Phillyrea angustifolia

Olea europea

Rubia peregrina

Stipa bromoides.

Rhamnus alaternus

Smilax aspera

Scabiosa columbaria

Lonicera etrusca

Dorycnium pentaphyllum

Hippocrepis commosa

Brachypodium retusum

Galium timeroyi

Cytisophyllum sessilifolium

Phillyrea latifolia

Clematis flammula

Peucedanum cervaria

Quercus pubescens

Anthoxanthum odoratum

Bituminaria bituminosa

Viola odorata

Rubus ulmifolius

Lavandula latifolia

Rubus caesius

Ulmus minor

Vicia tetrasperma

Brachypodium phoenicoides

Acer monpeliensis

Avenula bromoides

Cornus sanguinea

Leucanthemum vulgare

Lonicera periclymenum

Ulex minor

Amelanchier ovalis

Crataegus monogyna

Digitalis lutea

Daucus carota

Fraxinus angustifolia

Linum campanulatum

Lolium perenne

Ononis minutissima

Prunus avium

Prunus spinosa

Stachys recta

Teucrium chamaedrys

Reseda phyteuma

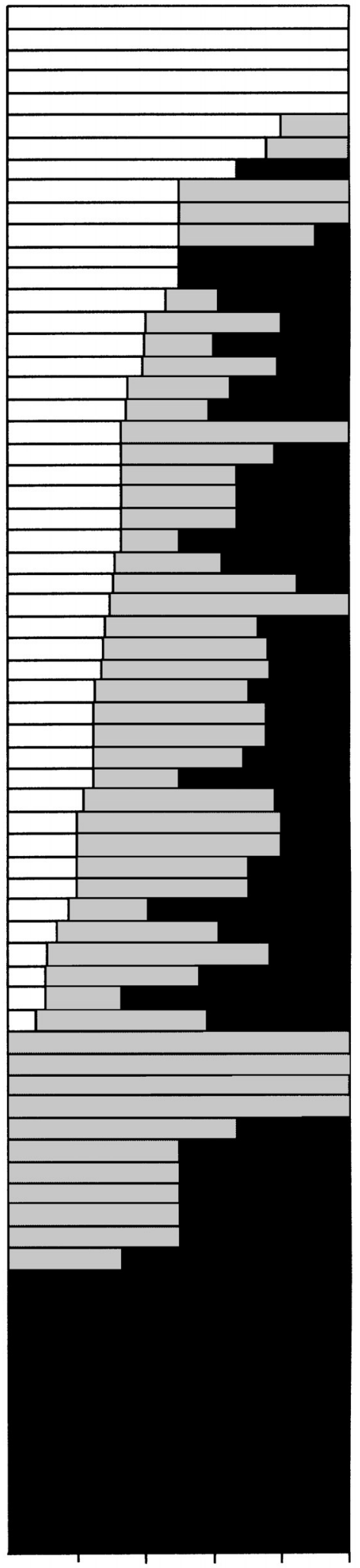

$\begin{array}{llllll}0 \% & 20 \% & 40 \% & 60 \% & 80 \% & 100 \%\end{array}$

Figure 1. Relative frequencies of plant species in the ground surface types in both studied areas. Intact spots are white, slash depot are grey and perturbed spots are black. Common species found in both areas are in bold. 


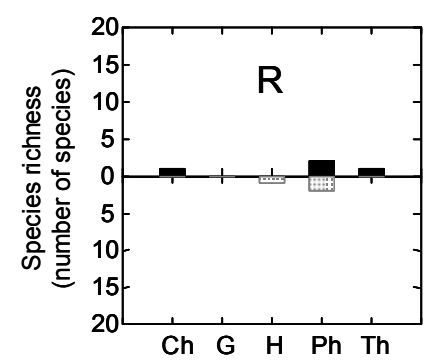

MED
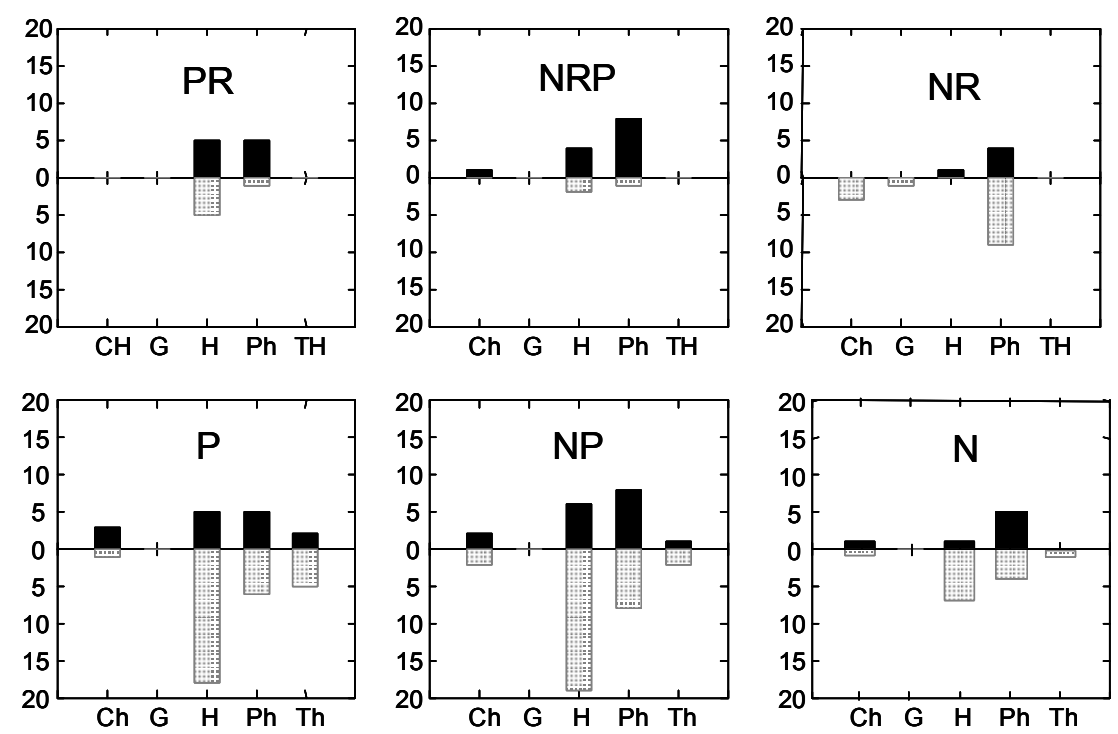

Figure 2. Species richness in terms of life forms defined by Raunkiær according to the group of affinity of the species for ground surface type and the area. ATL: Atlantic area, MED: Mediterranean area. Ch: Chamaephyte, $\mathrm{H}$ : Hemicryptophyte, $\mathrm{Ph}$ : Phanerophyte, G: Geophyte, Th: Therophyte.

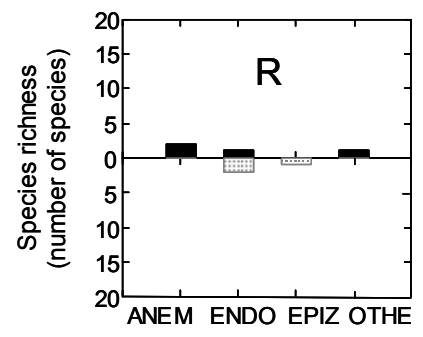

MED

槅 ATL
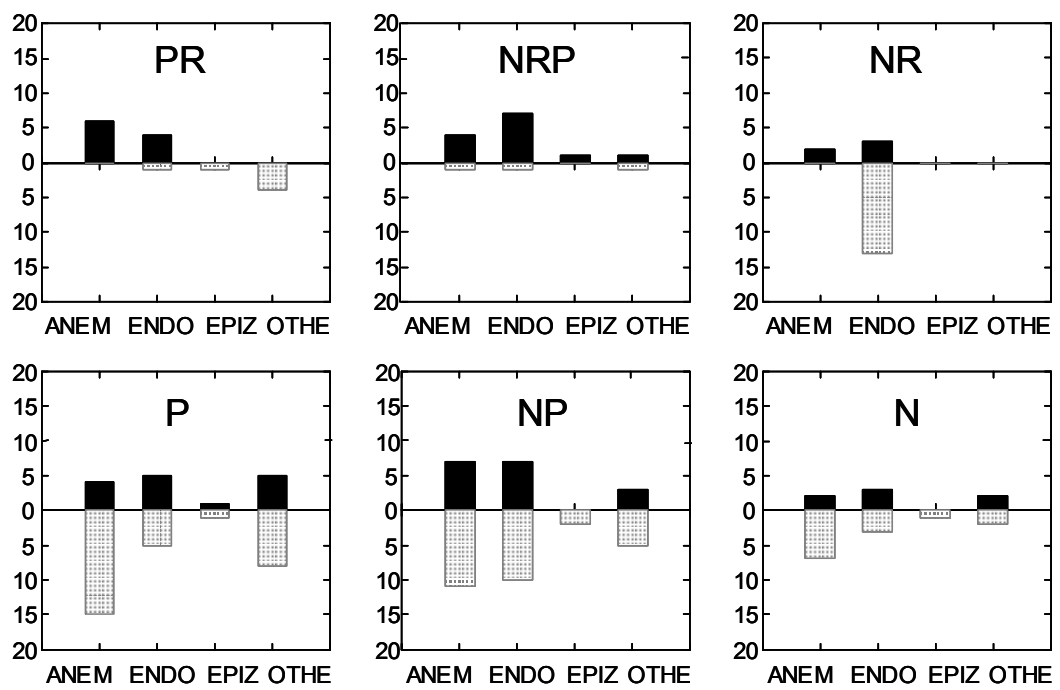

Figure 3. Species richness in terms of dispersal modes according to the group of affinity of the species for ground surface type and the area. ATL: Atlantic area, MED: Mediterranean area. Anem: anemochory; Endo: endozoochory and dispersal associated to animal feeding; Epiz: epizoochory; Othe: other or unknown dispersal modes. 


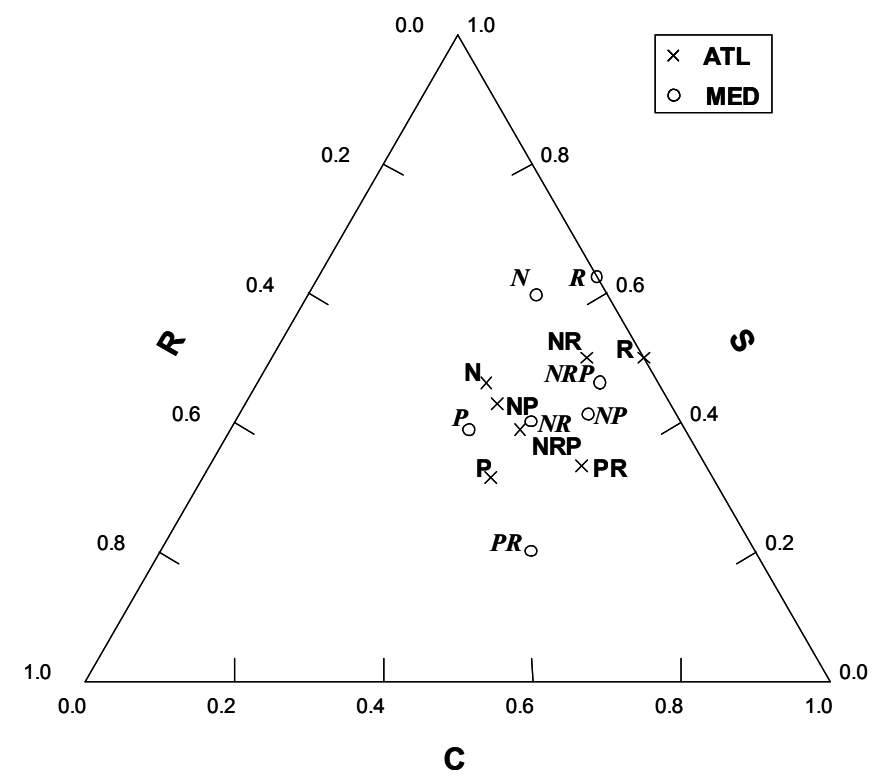

Figure 4. Mean position of the plant groups defined by their affinity to ground surface status in the Grime triangle defined by the sensitivity to perturbation ( $\mathrm{R}$ axe), to competition ( $\mathrm{C}$ axe) and to stress ( $\mathrm{S}$ axe).

and Mediterranean, few species were observed when remnant depots were high, while many species were present in perturbed places and numerous species were associated with not perturbed places or were indifferent to perturbation. These results agree with many other studies showing that logging increases plant species diversity $[32,53]$. However, plant species in the Mediterranean site had a lower affinity to ground surface types than in the Atlantic site. The low number of species associated with remnant depots can be explained by the fact that remnants compensate for canopy suppression due to logging by maintaining low light availability, high humidity and ample leaf litter [54]. Concerning the 14 species occurring in both the Atlantic and Mediterranean areas, only 6 species have similar trends with ground surface type. This variability in species response to perturbation could be explained by low plant species frequency. Moreover, all species which have been recorded in stands studied, which have been logged since than less than 3 years, are common species. Analyses of vegetation composition in similar stands, logged since 30 years, also indicated that no rare species were observed in both area [13, 25]. Thus when canopy closes and species richness decrease, there are no rare species that enhanced conservation value.

Hypothesis (2), i.e., that groups of plant species have distinct biological traits, was partially verified. Indeed, the analyses showed that perturbed areas $(\mathrm{P})$ were associated more particularly with hemicryptophytes, anemochorous and ruderal species; remnant depot (R) areas with seeds dispersed by animals and competitive species; and not perturbed $(\mathrm{N})$ areas with seeds dispersed by wind or animals and stress tolerant species. There was no life form which characterized in particular R or N. As in previous studies [4, 20, 26, 28], we found that hemicryptophytes increased after logging and we specified here that they increased more particularly in perturbed places. These plant species were essentially dispersed by wind and required perturbed areas, without litter, to germinate. Moreover, hemicryptophytes have a short life span and were probably not present in litter before logging. These forest and farm species probably arrived from the surrounding mosaic of forests and agricultural lands (essentially olive trees and vineyards in the Mediterranean area, and pastures and crops in the Atlantic area) [59]. Moreover, modalities of implantation of plant species depend on colonization pressure which is in turn heavily influenced by proximity to the logged forest. The temporal variation in plant diversity could also be analyzed. Indeed, plant diversity has been generally studied in relation to succession, few studies have addressed seasonal variation in plant diversity [but see 33, 67]. Concerning Grime strategies, plant species were globally speaking more competitive and stress tolerant than ruderal. This supposes that ground surface perturbations were so frequent and moderate that they were considered like a stress and not a perturbation by plant species.

The life traits selected in our study are relatively general, they synthesize other life traits as for example life forms that integrate both morphological and physiological criteria. But, all the possible life traits (leaf type, leaf consistency, nutrition type, vegetative multiplication etc.) were not available for the analysis because of lack of data on numerous species and also because of a discrepancy between the databases of life traits created separately in the two studies here compared. However, we found the same pattern in both areas, Atlantic and Mediterranean, for life forms and the dispersal modes; for Grime strategies, the species repartition in function of ground surface types was more stronger in Atlantic than in the Mediterranean area. Thus, hypothesis (3), that two different bio-geographic plant communities should have the same biological traits for a given soil surface disturbance, was not clearly verified. We conclude that life traits are a good tool to analyze ecosystem responses to disturbances such as logging. Expressing and grouping plant species primarily with regards their biological characteristics allows avoiding taxonomic attribution and thus, allows comparing result between two bio-geographic different sites.

The consequences of these sets of observations are that ground surface status influence plant species diversity. Thus, light availability and the related factors of moisture decrease, temperature modification, etc., cannot be considered as the only factor driving plant species diversity increase after logging. Moreover, the consequences of logging by different types of engines with increasing weight on the ground surface should be more carefully studied in order to be able to predict their influences on the vegetation.

Acknowledgements: We would like to thank the French Research Ministry, the Institut National de la Recherche Agronomique and the Société pour l'Exploitation des Bois du Sud Ouest for financial and technical support of the study in the Atlantic area. We also thank the European Union (DG XII), the Direction de l'Espace Rural et de la Forêt of the French Ministry of the Agriculture, the Centre National de la Recherche Scientifique, the Office National des Forêts, the Centre Régional de la Propriété Forestière, the Association Forêt Cellulose and the Société pour l'Exploitation des Forêts de l'Est for financial and technical support of the study in Mediterranean area. We also thank James Aronson for helpful comments on the manuscript. 


\section{REFERENCES}

[1] Anderson R.C., Loucks O.L., Swain A.M., Herbaceous response to canopy cover, light intensity, and throughfall precipitation in coniferous forests, Ecology 50 (1969) 255-263.

[2] Arsenault A., Bradfield G.E., Structural-compositional variation in three age-classes of temperate rainforests in southern British Columbia, Can. J. Bot. 73 (1995) 54-64.

[3] Barbéro M., Loisel R., Quézel P., Richardson D.M., Romane F., Pines of the Mediterranean Basin, in: Richardson D.M. (Ed.), Ecology and biogeography of Pinus, Cambridge University Press, Cambridge UK, 1998, pp. 153-170.

[4] Bartolome J.W., Allen-Diaz B.H., Tietje W.D. The effect of Quercus douglasii removal on understorey yield and composition, J. Range Manage. 47 (1994) 151-154.

[5] Blondel J., Biogéographie évolutive, Masson, Paris, 1986, 221 p.

[6] Bonnier G., Doin R., La grande flore illustrée en couleur de Gaston Bonnier, France, Suisse, Belgique et pays voisins, 4 vol., Belin, Paris, 1990, 1392 p.

[7] Brakenhielm S., Lui Q., Long-term effects of clear-felling on vegetation dynamics and species diversity in boreal pine forest, Biol. Conserv. 7 (1998) 207-220.

[8] Burton P.J., Balisky A.C., Coward L.P., Cumming S.G., Kneeshaw D.D., The value of managing for biodiversity, For. Chron. 68 (1992) 225-237.

[9] Chen J., Franklin J.F., Spies T.A., Contrasting microclimates among clearcut, edge, and interior of old-growth Douglas-fir forest, Agric. For. Meteorol. 63 (1993) 219-237.

[10] Collins B.S., Pickett S.T.A., Influence of canopy opening on the environment and herb layer in southern hardwood forest, Vegetatio 70 (1987) 3-10.

[11] Crawford Zimmerman J., DeWald L.E., Rowlands P.G., Vegetation diversity in an interconnected ephemeral riparian system of north-central Arizona, USA, Biol. Conserv. 90 (1999) 217-228.

[12] De Bolòs O., Vigo J., Masalles R.M., Ninot J.M., Flora manual dels països Catalans, Portic S.A., Barcelone, 1993, 1247 p.

[13] Deconchat M., Exploitation forestière et biodiversité : exemple dans les forêts fragmentées des coteaux de Gasgogne, Thèse de Doctorat de l'Université Paul sabatier, Université Toulouse III, 1999, $191 \mathrm{p}$.

[14] Deconchat M., Effets des techniques d'exploitation forestière sur l'état de surface du sol, Ann. For. Sci. 58 (2001) 653-661.

[15] Deconchat M., Balent G., Effets des perturbations du sol et de la mise en lumière occasionnées par l'exploitation forestière sur la flore à une échelle fine, Ann. For. Sci. 58 (2001) 315-328.

[16] Díaz S., Cabido M., Plant functional types and ecosystem function in relation to global change, J. Veg. Sci. 8 (1997) 463-474.

[17] Díaz S., Cabido M., Zak M., Martinez Carretero E., Aranibar J., Plant funtional traits, ecosystem structure and land-use history along a climatic gradient in central-western Argentina, J. Veg. Sci. 10 (1999) 651-660.

[18] Ebrecht L., Schmidt W., Nitrogen mineralization and vegetation along skidding tracks, Ann. For. Sci. 60 (2003) 733-740.

[19] Ehrlich P.R., Conservation in temperate forests: What do we need to know and do?, For. Ecol. Manage. 85 (1996) 9-19.

[20] Elliot K.J., Swank W., Changes in tree species diversity after successive clearcuts in the Southern Appalachians, Vegetatio 155 (1994) 11-18

[21] Federer C.A., Tanner C.B., Spectral distribution of light in the forest, Ecology 47 (1966) 555-560.

[22] Floret C., Galan M.J., Le Floc'h E., Orshan G., Romane F., Local characterization of vegetation through growth forms: Mediterranean Quercus ilex coppice as an example, Vegetatio 7 (1987) 3-11.

[23] Floret C., Galan M.J., Le Floc'h E., Orshan G., Romane F., Growth forms and phenomorphology traits along an environmental gradient: tools for studying vegetation? J. Veg. Sci. 1 (1990) 71-80.
[24] Gachet S., 2000. A tool to elaborate plant functional types: the floristic database BASECO, Workshop "Groupes fonctionnels : concepts et applications", Centre d'Ecologie Fonctionnelle et Evolutive, Ecole Nationale Supérieure d'Agronomie de Montpellier, Montpellier, 25-26.09.2000, http://www.imep-cnrs.com/pages/baseco.htm.

[25] Gondard H., Un facteur de la diversité végétale sous climat méditerranéen : l'exploitation forestière. Cas des peuplements de pin d'Alep (Pinus halepensis) du Sud de la France, Thèse de Doctorat, Université Aix-Marseille III, 2001, 157 p.

[26] Gondard H., Aronson J., Grandjanny M., Le Floc'h E., Renaux A., Romane F., Shater Z., Plant species richness response to management practices in chestnut (Castanea sativa Miller) forests and coppice stands in the Cévennes mountains (southern France), Ecol. Medit. 26 (2000) 143-154.

[27] Gondard H., Romane F., Aronson J., Shater, Z., Impact of soil surface disturbances on functional group diversity after clearcutting in Aleppo pine (Pinus halepensis) forests in southern France, For. Ecol. Manage. 180 (2003) 165-174.

[28] Gondard H., Romane F., Grandjanny M., Li J., Aronson J., Plant species diversity changes in abandoned chestnut (Castanea sativa Miller) groves in southern France, Biodivers. Conserv. 10 (2001) 189-207.

[29] Grime J.P., Evidence for the existence of three primary strategies in plants and its relevance to ecological and evolutionary theory, Am. Nat. 111 (1977) 1169-1193.

[30] Grime J.P., Hodgson J.G., Hunt R., Comparative plant ecology. A functional approach to common British species, Unwin Hyman Ltd, London, UK, 1988, 742 p.

[31] Hadar L., Noy-Meir I., Perevolotsky A., The effect of shrub clearing and grazing on the composition of a Mediterranean plant community: functional groups versus species, J. Veg. Sci. 10 (1999) 673-682.

[32] Halpern C.B., Spies T.A., Plant species diversity in natural and managed forests of the Pacific Northwest, Ecol. Appl. 5 (1995) 913-934.

[33] Holland P.G., Seasonal change in the shoot flora diversity of hardwood forest stands on Mont St. Hilaire, Quebec, Can. J. Bot. 49 (1971) 1713-1720.

[34] Host G.E., Pregitzer K.S., Ecological species groups for upland forest ecosystems of northwestern Lower Michigan, For. Ecol. Manage. 43 (1971) 87-102.

[35] Huston M.A., Hidden treatments in ecological experiments: reevaluating the ecosystem function of biodiversity, Oecologia 110 (1997) 449-460.

[36] Jauzein P., Flore des champs cultivés, Édition INRA, Paris, 1995, 898 p.

[37] Kropp B.R., Albee S., The effects of sylvicultural treatments on occurence of mycorrhizal sporocarps in a Pinus contorta forest: a preliminary study, Biol. Conserv. 78 (1996) 313-318.

[38] Landsberg J., Lavorel S., Stol J., Grazing response groups among understorey plants in arid rangelands, J. Veg. Sci. 10 (1999) 683696.

[39] Lavagne A., Moutte, P., Commentaires de la carte phytosociologique de Draguignan au 1/100 $000^{\mathrm{e}}$, Revue Biologie, Écologie méditerranéenne VII (1980) 265-312.

[40] Lavorel S., McIntyre S., Landsberg J., Forbes T.D.A., Plant functional classification: from general groups to specific groups based on response to disturbance, Trends Ecol. Evol. 12 (1997) 474-478.

[41] Lavorel S., Rochette C., Lebreton J.-D., Functional groups for response to disturbance in Mediterranean old fields, Oikos 84 (1999) 480-498.

[42] Lavorel S., Touzard B., Lebreton J.D., Clément B., Identifying functional groups for response to disturbance in an abandoned pasture, Acta Oecologica 19 (1998) 227-240.

[43] Leps J., Osbornova-Kosinova J., Rejmanek M., Community stability, complexity and species life history strategies, Vegetatio 50 (1982) 53-63. 
[44] Likens G.E., Bormann F.H., Pierce R.S., Reiners W.A., Recovery of deforested ecosystem. Replacing the biomass nutrients lost in harvesting northern hardwood may take 60 to 80 years, Science 199 (1978) 492-496.

[45] McIntyre S., Lavorel S., Livestock grazing in sub-tropical pastures: steps in the analysis of attribute response and plant functional types, J. Ecol. 89 (2001) 209-226.

[46] McIntyre S., Lavorel S., Landsberg J., Forbes T.D.A., Disturbance response in vegetation - towards a global perspective on functional traits, J. Veg. Sci. 10 (1999) 621-630.

[47] McIntyre S., Lavorel S., Tremont R.M., Plant life-history attributes: their relationship to disturbance response in herbaceous vegetation, J. Ecol. 83 (1995) 31-44.

[48] McMahon S., A survey method for assessing site disturbance, Logging Industry Research Organisation: Rotorua, New Zealand, $1995,16 \mathrm{p}$.

[49] Molinier R., Müller P., La dissémination des espèces végétales, Lesot A., Paris, 1938, 178 p.

[50] Montalvo J., Casado M.A., Levassor C., Pineda F.D., Adaptation of ecological systems: compositional patterns of species and functional traits, J. Veg. Sci. 2 (1991) 655-666.

[51] Mou P., Fahey T.J., Hughes J.W., Effects of soil disturbance on vegetation recovery and nutrient accumulation following wholetree harvest of a Northern hardwood ecosystem, J. Appl. Ecol. 30 (1993) 661-675.

[52] Noble I.R., Dirzo R., Forest as human-dominated ecosystems, Science 277 (1997) 522-525.

[53] North R., Chen J.Q., Smith G., Krakowiak L., Franklin J., Initial response of understory plant diversity and overstory tree diameter growth to a green tree retention harvest, Northwest Sci. 70 (1996) 24-35.

[54] Olsson B.A., Staaf H., Influence of harvesting intensity of logging residue on ground vegetation in coniferous forests, J. Appl. Ecol. 32 (1995) 640-654
[55] Orshan G., Plant pheno-morphological studies in Mediterranean type ecosystems, in: Orshan G. (Ed.) Geobotany, Kluwer Academic Publishers, Dordrecht, The Netherlands, 1989, 404 p.

[56] Pennock D.J., Vankessel, C., Clear-cut forest harvest impacts on soil quality indicators in the mixedwood forest of Saskatchewan, Canada, Geoderma 75 (1997) 13-32.

[57] Pignatti S., Flora d'Italia, Edagricole (Ed.), Bologne, 1982, 2302 p.

[58] Pimm S.L., The complexity and stability of ecosystems, Nature 307 (1984) 321-326.

[59] Qi M.Q., Scaratt J.B., Effect of harvesting method on seed bank dynamics in a boreal mixed wood forest in northwestern Ontario, Can. J. Bot. 76 (1998) 872-883.

[60] Quézel P., Barbéro M.,. Le pin d'Alep et les espèces voisines : répartition et caractères écologiques généraux, sa dynamique récente en France méditerranéenne, For. Méditerr. 13 (1992) 158 170.

[61] Rameau J.C., Définition et évaluation de la qualité d'un écosystème forestier, Forêt Wallone 39-40 (1999) 37-51.

[62] Rameau J.C., Mansion D., Dumé G., Flore Forestière Française Guide écologique illustré. Plaines et collines, Institut Développement Forestier, Dijon, France, 1989, 1785 p.

[63] Raunkiær C., The life forms of plants and statistical plant geography, Oxford University Press, Oxford, 1934, 632 p.

[64] SYSTAT Systat (R) 9.0 for Windows (R) Statistics I, SPSS, Chicago, USA, 1999, $690 \mathrm{p}$.

[65] van der Pijl L., Principles of dispersal in higher plants, Springer, Berlin, Heidelberg and New York, 1982, 167 p.

[66] Weiher E., van der Werf A., Thompson K., Roderick M., Garnie E., Ericksson O., Challenging Theophrastus: A common core list of plant traits for functional ecology, J. Veg. Sci. 10 (1999) 603-730.

[67] Yorks T.E., Dabydeen S., Seasonal and successional understory vascular plant diversity in second-growth hardwood clearcuts of western Maryland, USA, For. Ecol. Manage. 119 (1999) 217-230. 